\title{
Granulocyte-macrophage colony-stimulating factor does not increase the potency or efficacy of a foot-and-mouth disease virus subunit vaccine ${ }^{1}$
}

\author{
Luizinho Caron², Mario C.S. Brum², Mauro P. Moraes ${ }^{2,3}$, William T. Golde ${ }^{2}$, Clarice \\ Weis $\mathrm{Arns}^{4}$ and Marvin J. Grubman ${ }^{2 *}$
}

\begin{abstract}
Caron L., Brum M.C.S., Moraes M.P., Golde W.T., Arns C.W. \& Grubman M.J. 2005. [Granulocyte-macrophage colony-stimulating factor does not increase the potency or efficacy of a foot-and-mouth disease virus subunit vaccine.] Pesquisa Veterinária Brasileira 25(3):150-158. USDA, ARS, PIADC-FMD Research Unit, PO.Box 848, Greenport, NY 11944 0848, USA.E-mail: mgrubman@piadc.ars.usda.gov

Foot-and-mouth disease (FMD) is one of the most feared diseases of livestock worldwide. Vaccination has been a very effective weapon in controlling the disease, however a number of concerns with the current vaccine including the inability of approved diagnostic tests to reliably distinguish vaccinated from infected animals and the need for high containment facilities for vaccine production, have limited its use during outbreaks in countries previously free of the disease. A number of FMD vaccine candidates have been tested and a replication-defective human adenovirus type 5 (Ad5) vector containing the FMDV capsid (P1-2A) and 3C protease coding regions has been shown to completely protect pigs against challenge with the homologous virus (FMDV A12 and A24). An Ad5-P1-2A+3C vaccine for FMDV 01 Campos (Ad5-O1C), however, only induced a low FMDV-specific neutralizing antibody response in swine potency tests. Granulocyte-macrophage colony-stimulating factor (GM-CSF) has been successfully used to stimulate the immune response in vaccine formulations against a number of diseases, including HIV, hepatitis $\mathrm{C}$ and $\mathrm{B}$. To attempt to improve the FMDV-specific immune response induced by Ad5-O1C, we inoculated swine with Ad5$\mathrm{O} 1 \mathrm{C}$ and an Ad5 vector containing the gene for porcine GM-CSF (pGM-CSF). However, in the conditions used in this trial, pGM-CSF did not improve the immune response to Ad5-01C and adversely affected the level of protection of swine challenged with homologous FMDV.
\end{abstract}

INDEX TERMS: Foot-and-mouth disease virus 01 Campos, Adenovirus, Granulocyte-macrophage colonystimulating factor.

RESUMO.- [Fator Estimulante de Colônias de Granulócitos e Macrófagos (GM-CSF) não aumenta a eficácia ou potência da vacina de subunidades da Febre Aftosa em suínos.] A febre aftosa é uma das doenças mais temidas nos rebanhos em todo o mundo. A vacinação tem sido uma arma eficiente no controle da doença, no entanto há preocupações com as vacinas atualmente utilizadas incluindo a necessidade de

\footnotetext{
${ }^{1}$ Received on July 12, 2004.

Accepted for publication on December 17, 2004.

${ }^{2}$ USDA, ARS, PIADC-FMD Research Unit, P.O.Box 848, Greenport, NY 11944 0848, USA. "Corresponding author. E-mail: mgrubman@piadc.ars.usda.gov

${ }^{3}$ Current address: Department of Veterinary Virology, Federal University of Viçosa, 36571-000 Viçosa, MG, Brazil.

${ }^{4}$ Current address: Laboratório de Virologia Animal, DMI, IB, Unicamp, Cx.Postal 6109, Campinas, SP 13083-862, Brazil.
}

instalações de alta segurança para a produção dessas vacinas e a falta de um teste de diagnóstico aprovado que faça distinção precisa entre animais vacinados dos infectados. Várias vacinas têm sido testadas contra a febre aftosa e uma dessas utiliza como vetor um vírus defectivo para replicação, derivado do adenovírus humano tipo 5 (Ad5), o qual contém as proteínas que compõe capsídeo do vírus da febre aftosa (P1-2A) e a protease $3 \mathrm{C}$, protegeu completamente suínos contra o desafio de uma cepa homóloga (A12 e A24). Uma vacina com o Ad5-P1-2A+3C proveniente da cepa 01 Campos (Ad5-O1C), no entanto, somente induziu um baixo título de anticorpos neutralizantes específicos em testes de potência vacinal em suínos. $O$ fator estimulante de colônias de granulócitos e macrófagos (GM-CSF) tem sido utilizado com sucesso na formulação de vacinas para estimular a resposta imune contra inúmeras doenças, incluindo HIV, Hepatite C e B. Na tentativa de melhorar a resposta imune específica contra 
a febre aftosa induzida pelo Ad5-01C, suínos foram vacinados com Ad5-O1C juntamente com Ad5-GM-CSFporcino. Entretanto nas, condições utilizadas nesse teste, o GM-CSF suíno não melhorou a resposta imune do Ad5-01C e adversamente afetou o nível de proteção de suínos desafiados com o vírus homólogo da febre aftosa.

TERMOS DE INDEXAÇÃO: Febre Aftosa Vírus 01 Campos, Adenovirus, Fator Estimulante de Colônias de Granulócitos e Macrófagos.

\section{INTRODUCTION}

Foot-and-mouth disease (FMD) is a highly contagious, acute disease of domestic and wild cloven-hoofed animals (Callis \& McKercher 1986, Donaldson et al. 1986). The etiologic agent, FMD virus (FMDV), is a member of the Aphthovirus genus Picornaviridae family (Murphy et al. 1999) and contains a singlestranded, positive-sense RNA genome of approximately 8.5kb. The virus consists of seven serotypes ( $O, A, C$, SAT 1-3 and Asia) and multiple subtypes within each serotype.

FMD outbreaks can result in significant economic losses in disease-free countries due to direct and indirect costs, most of which are related to international trade embargoes of animals and animal products. Recent outbreaks in Taiwan and the United Kingdom have highlighted the major risk of introduction and rapid spread of FMD in a susceptible population (Mathews 2001). Currently, conventional binary ethyleinimine (BEI) inactivated vaccines emulsified with adjuvant have been widely used in effective control and eradication programs around the world (Brownlie 2001). However, there are no approved diagnostic tests that can reproducibly differentiate vaccinated from infected/ convalescent animals. Furthermore, conventional vaccines require growth and inactivation of live virus in containment facilities and introduce the potential for escape of live virus or incomplete inactivation (Barteling \& Vreeswijk 1991). As a result some FMD-free countries have not considered vaccination as part of their disease control strategy.

Several approaches are being used to develop alternative FMD vaccines that address these concerns, including construction of modified live-virus (Mason et al. 1997, Almeida et al. 1998), biosynthetic proteins (Kleid et al. 1981, McKercher et al. 1985), synthetic peptides (Bittle et al. 1982, Clark et al. 1983, Brown 1988, Blanco et al. 2001), naked DNA vectors (Ward et al. 1997, Chinsangaram et al. 1998, Wong et al. 2000, Benvenisti et al. 2001, Cedillo-Barrón et al. 2001), and recombinant viruses (Sanz-Parra et al. 1999a,b, Mayr et al. 1999, 2001, Berinstein et al. 2000, Moraes et al. 2002, Wu et al. 2003b). However, most of these approaches have either been unsuccessful in both swine and cattle or require multiple inoculations to induce protection.

Human adenovirus (Ad5) has been used as a vector for FMD vaccines encoding the capsid (P1-2A) (Sanz-Parra et al. 1999a,b) or P1-2A and $3 \mathrm{C}$ protease coding regions of FMDV (Mayr et al. 1999, 2001, Moraes et al. 2002, Wu et al. 2003b). Inoculation with one dose of Ad5 containing the serotypes A24 Cruzeiro P1$2 \mathrm{~A}$ and $\mathrm{A} 123 \mathrm{C}$ coding regions (Ad5-A24) protected swine from direct inoculation challenge with homologous virus (Moraes et al. 2002). More recently we have attempted to develop Ad5 vaccine vectors for other FMDV serotypes, in particular isolates of serotype $O$ that are currently causing disease outbreaks throughout the world. We have constructed Ad5 and Ad2 vectors containing the $\mathrm{P} 1-2 \mathrm{~A}$ region of $\mathrm{O} 1 \mathrm{Campos}$ and the $3 \mathrm{C}$ of $\mathrm{A} 12$ (Ad5-01C) and found that swine inoculated with these vectors developed a lower FMDV-specific neutralizing antibody response than Ad5-A24 inoculated animals (unpublished data). Likewise, swine inoculated with an Ad5-FMD bivalent vaccine containing the $\mathrm{P} 1-2 \mathrm{~A}$ regions from $\mathrm{A} 24$ Cruzeiro and $\mathrm{O} 1 \mathrm{C}$ developed a higher neutralizing antibody response against $\mathrm{A} 24$ than against $\mathrm{O} 1 \mathrm{Wu}$ et al., 2003b). It has been established that serotype $O$ antigen induces a lower immune response as compared to serotype $\mathrm{A}$ antigen (Pay \& Hingley 1987, Doel et al. 1994). Because of this commercial vaccines usually contain about 4-5 times more 01 inactivated virus (146S antigen) than A 146 S antigen.

The use of cytokines to modulate responses against immunization with DNA and recombinant virus vectors is being actively investigated. Granulocyte-macrophage colonystimulating factor (GM-CSF), a hematopoietic growth factor, has been widely used as a molecular adjuvant to induce immunity. GM-CSF activates neutrophils, macrophages, dendritic cells (DCs), and other mononuclear cells, and also stimulates progenitor/ stem cells to mature and migrate from the bone marrow to the peripheral circulation (Kusakabe et al. 2000). Intramuscular (IM) inoculation of the GM-CSF gene together with plasmids carrying viral genes, such as those encoding the glycoprotein of rabies virus and VP1 of encephalomyocarditis virus, increased antigenspecific immune responses and protective immunity in mice as compared to inoculation with the plasmid containing only the viral gene (Xiang \& Ertl 1995, Sin et al. 1997). Somasundaram et al. (1999) found an adjuvant effect of porcine GM-CSF (pGM-CSF) on a DNA vaccine containing the $\mathrm{gD}$ and $\mathrm{gB}$ glycoprotein genes of Aujeszky's disease virus (PRV) in pigs. This effect was characterized by an early appearance of anti-PRV IgG2, a significantly enhanced anti-PRV $\operatorname{IgG} 1$ and $\operatorname{IgG} 2$ antibody response, a significantly decreased and shortened period of virus shedding in nasal swabs and improved protection against viral challenge. In contrast, co-administration of porcine IFN- $\gamma$ or IL-2 had no adjuvant effect.

Lee et al. (1998), observed that both humoral and cellular immune responses to hepatitis $\mathrm{C}$ virus (HCV) envelope proteins were augmented in rats by the co-delivery of the GM-CSF gene. Moreover, inoculation of bicistronic plasmids elicited higher levels of antibody and lymphoproliferative responses than did the co-inoculation of two independent expression plasmids that encoded the GM-CSF gene and each HCV envelope gene. Similarly Barouch et al. (2002) demonstrated that a bicistronic plasmid containing GM-CSF and HIV gp120 elicited a dramatic augmentation of vaccine-elicited $\mathrm{CD} 4^{+} \mathrm{T}$ cell responses in mice as compared to gp120 alone or individual plasmids containing each gene. These results suggest that the local concentration of GM-CSF may be a critical factor that contributes to the enhancement of the immune response to the co-expressed antigens. It has also been demonstrated that the time of administration of GM-CSF with respect to the DNA antigen vaccine can profoundly influence the nature of the Th1/Th2 balance of an antigen-specific immune response (Kusakabe et al. 2000). 
We have tested pGM-CSF as an adjuvant for our Ad5-01C vaccine and have delivered this cytokine with a recombinant Ad5 vector. We have previously utilized the Ad5 vector system to effectively deliver various cytokines including type I interferons $(\mathrm{IFN}-\alpha / \beta$ ) to swine (Chinsangaram et al. 2003, Moraes et al. 2003; Wu et al., 2003a) and cattle (Wu et al., 2003a). Swine inoculated with both Ad5-pGMCSF and Ad5-O1C, however, did not develop an enhanced immune response against $\mathrm{O} 1 \mathrm{C}$ as compared to Ad5-O1C inoculated animals and administration of pGM-CSF had an adverse effect on the degree of protection afforded by the Ad5-O1C vaccine.

\section{MATERIALS AND METHODS}

\section{Virus and cells}

All adenovirus clones were generated, grown, and titered in human 293 cells (Graham et al. 1977, Graham \& Prevec 1991), between passages 20 and 30 . Plaque reduction neutralization assays with FMDV were performed in baby hamster kidney 21 cells (BHK-21) between passages 62 and 70. TF-1 cells, obtained from the American Type Culture Collection, are an indicator cell clone that is dependent on human GM-CSF or IL-3 for growth. These cells were used to analyze the biological activity of pGMCSF obtained from the supernatants of IB-RS-2 cells (Instituto Biológico-Rim Suíno 2) infected with Ad5-pGMCSF, as pGM-CSF supports growth of this cell line as well.

\section{Construction of recombinant adenoviruses Ad5- pGMCSF and Ad5-01C}

The pGM-CSF gene, containing the signal sequence, was obtained from plasmid p3Cla-pGM-CSF kindly provided by Dr. Steve Martin, Pharmacia-UpJohn. This plasmid was digested with HindIII and EcoRI, ligated to similarly digested pBluescript II KS (Stratagene, La Jolla, CA) and chemically transformed into Top 10 competent cells (Invitrogen, Carlsbad, CA) to generate the plasmid, pKSII-pGMCSF. The coding sequence of pGM-CSF was removed from pKSII-pGMCSF by digestion with ClaI and Xbal and ligated into similarly digested pAd5-Blue (Moraes et al. 2001) to generate the infectious clone pAd5-pGMCSF. Recombinant virus Ad5-pGMCSF was produced by transfection of 293 cells with Pacl digested pAd5-pGMCSF following the protocol described (Wu et al., 2003b). The virus was isolated, propagated in 293 cells, and purified by $\mathrm{CsCl}$ gradient centrifugation (Mayr et al., 1999; Moraes et al., 2002).

To construct Ad5-O1C, the infectious clone pCRM8 (Sá-Carvalho et al., 1997) a chimeric FMDV clone containing the P1-2A coding region of FMDV $\mathrm{O} 1 \mathrm{C}$ in the background of FMDV A12, was digested with $\mathrm{Ncol}$, Apal to remove the $01 \mathrm{C} P 1-2 \mathrm{~A}$ coding region. Plasmid pP12X3C (Mayr et al., 1999), which contains the complete $\mathrm{P} 1-2 \mathrm{~A}$ and $3 \mathrm{C}$ coding regions and partial $2 \mathrm{~B}$ and $3 \mathrm{~B}$ coding regions of FMDV A12, was digested with the same enzymes to remove the $\mathrm{A} 12 \mathrm{P} 1-2 \mathrm{~A}$ coding region and ligated to $\mathrm{O} 1 \mathrm{C} \mathrm{P} 1-$ $2 \mathrm{~A}$ to generate $\mathrm{pP} 1-2 \mathrm{~A}(\mathrm{O} 1 \mathrm{C}) \mathrm{X} 3 \mathrm{C}$. This plasmid was digested with BglII and Xbal to remove the O1C P1-2A and A12 3C coding regions and ligated to similarly digested $\mathrm{Ad} 5$ transfer vector pShuttle (He et al., 1998). pShuttle-P1-2A(O1C)X3C was digested with Clal and Xbal and the fragment containing the FMDV coding regions was ligated to similarly digested pAd5-Blue to generate pAd5-01C. Recombinant virus Ad5-O1C was produced by transfection of 293 with Pacl digested pAd5-O1C and purified virus prepared as described above. In both the Ad5-pGMCSF and Ad5-01C viruses the inserted coding regions are under the control of the cytomegalovirus (CMV) immediate early promoter (Moraes et al., 2001).

Expression of pGM-CSF and $01 \mathrm{C}$ capsid proteins synthesized in Ad5-pGMCSF or Ad5-01C infected cells

IB-RS-2 cells were grown in 6 well plates and infected with Ad5-pGMCSF or Ad5-O1C at a multiplicity of infection (moi) of 20. At 5 or $23 \mathrm{~h}$ postinfection (hpi), the cells were preincubated for 1 $\mathrm{h}$ in methionine-free culture medium in the absence or presence of $5 \mu \mathrm{g} / \mathrm{ml}$ tunicamycin, followed by radiolabeling for $1 \mathrm{~h}$ with $\left[{ }^{35} \mathrm{~S}\right]$ methionine in methionine-free medium in the absence or presence of tunicamycin. The supernatants were harvested, frozen at $-70^{\circ} \mathrm{C}$ and the cells were washed twice with PBS, lysed, centrifuged and the cytoplasmic extracts frozen at $-70^{\circ} \mathrm{C}$. Samples were immunoprecipitated with polyclonal goat anti-pGM-CSF antibody (R\&D Systems, Minneapolis, MN) or various FMDV-specific antisera as described in the captions to Figs. 1 and 3 and the immune complexes were precipitated with Streptococcus aureus protein G (Calbiochem, San Diego, CA) and analyzed by SDSpolyacrylamide gel electrophoresis (SDS-PAGE) on a $15 \%$ gel. The gels were dried and exposed to Kodak XDBF- $1{ }^{\circledR} \mathrm{X}$-ray film.

Alternatively IB-RS- 2 cells were infected at a moi of 20 with Ad5-pGMCSF for $24 \mathrm{~h}$. Supernatant fluids were harvested and centrifuged at $2000 \mathrm{rpm}$ for $10 \mathrm{~min}$. To remove the majority of virus inoculum, the supernatants fluids were filtered through a Centricon 100 filter (Millipore, Bedford, MA) and frozen in aliquots at $-70^{\circ} \mathrm{C}$. Aliquots were examined for pGM-CSF expression by Western blot analysis on a $10 \%$ precast polyacrylamide gel, (NuPAGE, Invitrogen) and transferred to a PVDF membrane (Millipore). Protein was detected using a polyclonal goat anti-pGM-CSF antibody (R\&D Systems), phosphatase labeled rabbit anti-goat polyclonal antibody, and BCIP/NBT phosphatase substrate following the manufacturer's instructions (KPL, Gaithersburg, MD).

\section{Biological activity of pGM-CSF synthesized in Ad5- pGMCSF infected cells}

Biological activity was measured using a Cell Proliferation ELISA System RPN 250 (BIOTRAK ${ }^{\circledR}$ Amersham Pharmacia Biotech, Piscataway, NJ). A standard curve was generated by growth of TF-1 cells, in 96-well tissue culture plates, in the presence of dilutions of recombinant pGM-CSF (R\&D Systems) (Kitamura et al., 1989). Dilutions of supernatant fluids from Ad5-pGMCSF infected IB-RS-2 cells were added, in duplicate, to a 96-well plate containing TF-1 cells. After 5 days incubation, bromodeoxyuridine (BrdU) was added and cells labeled for approximately $20 \mathrm{~h}$. Cell proliferation was measured following the manufacturers recommended protocol (Bautista et al. 2002).

\section{Animals}

Eighteen out-bred Yorkshire gilts approximately 7-8 weeks old, weighting between 35-40 lbs, were divided into five groups and each group was housed in a separate room in the highcontainment facilities at the PIADC. All animals were handled humanely according to protocols approved by the Animal Care and Use Committee (ACUC) of PIADC. The animals were observed for one week prior to the start of the experiment. The vaccine was administrated by IM inoculation in the neck with $2 \mathrm{ml}$ of various doses of Ad5 vectors in PBS (Table 1). All animals were challenged 21 days post vaccination (dpv) and $35 \mathrm{dpv}$ the remaining pigs were humanely euthanised.

\section{Serology and virus isolation}

Serum samples were obtained at 0 and 4 days after 
Table 1. Serum neutralization titers after vaccination and clinical scores

\begin{tabular}{|c|c|c|c|c|c|c|c|c|c|c|c|}
\hline \multirow[t]{2}{*}{ Animal } & \multirow[t]{2}{*}{ Group } & \multirow[t]{2}{*}{ Virus constructs } & \multirow[t]{2}{*}{ Dose (PFU/animal) } & \multirow{2}{*}{$\begin{array}{l}\text { Clinical } \\
\text { scores }^{\mathrm{b}}\end{array}$} & \multicolumn{7}{|c|}{ Weeks post-vaccination $\left(\mathrm{PRN}_{70}\right)^{\mathrm{a}}$} \\
\hline & & & & & 0 & $1 / 2^{c}$ & 1 & 2 & 3 (Challenge) & 4 & 5 \\
\hline 2107 & 1 & Ad5-Blue & $1 \times 10^{9}$ & 16 & $<8$ & $<8$ & $<8$ & $<8$ & $<8$ & Dead & \\
\hline 2108 & 1 & & & 18 & $<8$ & $<8$ & $<8$ & $<8$ & $<8$ & Dead & \\
\hline 2109 & 1 & & & 18 & $<8$ & $<8$ & $<8$ & $<8$ & $<8$ & Dead & \\
\hline 2110 & 2 & Ad5-pGMCSF & $1 \times 10^{9}$ & 17 & $<8$ & $<8$ & $<8$ & $<8$ & $<8$ & 160 & 1000 \\
\hline 2111 & 2 & & & 15 & $<8$ & $<8$ & $<8$ & $<8$ & $<8$ & Dead & \\
\hline 2112 & 2 & & & 17 & $<8$ & $<8$ & $<8$ & $<8$ & $<8$ & 640 & 1000 \\
\hline 2104 & 3 & Ad5-01C & $5 \times 10^{9}$ & 11 & $<8$ & $<8$ & 16 & 16 & $<16$ & 2560 & 2000 \\
\hline 2113 & 3 & & & 8 & $<8$ & $<8$ & $<8$ & 8 & $<16$ & 4000 & 1000 \\
\hline 2114 & 3 & & & 11 & $<8$ & $<8$ & 32 & 64 & 32 & 4000 & 2000 \\
\hline 2115 & 3 & & & 8 & $<8$ & $<8$ & 8 & 16 & 16 & 2560 & 2000 \\
\hline 2105 & 4 & Ad5-01C+ Ad5-pGMCSF & $5 \times 10^{9}+1 \times 10^{8}$ & 9 & $<8$ & 16 & 16 & 32 & 16 & 8000 & 2000 \\
\hline 2116 & 4 & & & 12 & $<8$ & 8 & 16 & 16 & $<16$ & 4000 & 2000 \\
\hline 2117 & 4 & & & 10 & $<8$ & 16 & 64 & 16 & $<16$ & 8000 & 8000 \\
\hline 2118 & 4 & & & 15 & $<8$ & 8 & 16 & 16 & $<16$ & 2560 & 4000 \\
\hline 2106 & 5 & Ad5-O1C + Ad5-pGMCSF & $5 \times 10^{9}+1 \times 10^{9}$ & 12 & $<8$ & 8 & 32 & 32 & 16 & 4000 & 4000 \\
\hline 2119 & 5 & & & 11 & $<8$ & 32 & 64 & 32 & 16 & 4000 & 4000 \\
\hline 2120 & 5 & & & 9 & $<8$ & 8 & 32 & 16 & $<16$ & 1240 & 4000 \\
\hline 2121 & 5 & & & 13 & $<8$ & 8 & 16 & 16 & $<16$ & 4000 & 2000 \\
\hline
\end{tabular}

a Serum dilution that reduces the number of plaques by $70 \%$; ${ }^{\text {b }}$ Clinical scores were determined by the number of toes presenting FMD compatible lesions plus the presence of lesions in the snout and mouth, with a maximum score of 18; we did not count a lesion found at the site of inoculation; the score listed was determined at $9 \mathrm{dpc}$ or the day of death; ${ }^{\mathrm{c}}$ Four days post-vaccination.

inoculation and weekly thereafter. Sera were tested for the presence of neutralizing antibodies against FMDV 01C, in a plaque reduction neutralization (PRN) assay. Neutralization titers were reported as the serum dilution yielding a $70 \%$ reduction in the number of plaques $\left(\mathrm{PRN}_{70}\right)$ (Moraes et al. 2002).

Heparinized blood was obtained prior to challenge and daily for 7 days postchallenge (dpc) and examined for the presence of virus by a standard plaque assay in BHK-21 cells. Nasal secretions were obtained on the same days as heparinized blood, inoculated into IB-RS-2 cells, and observed for $48 \mathrm{~h}$ for cytopathic effects. Negative samples were frozen and a second passage performed. For positive samples, titration was performed from the original samples by a plaque assay on BHK-21 cells.

\section{Challenge}

The 18 animals were challenged with homologous FMDV 01C 21 days after receiving the respective vaccine combinations (Table 1). FMDV 01C was provided by the Instituto Pan-Americano de Febre Aftosa, Rio de Janeiro (PANAFTOSA). This virus was passed 5 times in BHK-21 cells, and once each in a bovine and a pig. Virus was harvested from vesicles of an infected pig, diluted with MEM, centrifuged at $2000 \mathrm{~g}$ to remove debris, aliquoted, and frozen at $-70^{\circ} \mathrm{C}$. An aliquot was titrated in BHK-21 cells and in 4 pigs to determine the "pig heel infectious dose $50 \%$ " ( $\left.\mathrm{PHID}_{50}\right)$ as previously described (Burrows 1966). Pigs were infected with $100 \mathrm{PHID}_{50}$ by intradermal inoculation at 2 sites in the heel bulb of the rear feet.

\section{RESULTS}

\section{Ad5-pGMCSF and Ad5-01C expression}

IB-RS-2 cells were infected with Ad5-pGMCSF and at 6 or 24 hpi were radiolabeled with ${ }^{35} S \mid$ methionine in the absence or presence of $5 \mu \mathrm{g} / \mathrm{ml}$ tunicamycin. The cell culture supernatants were examined by SDS-PAGE. As can be seen in Fig. 1 (lane 2) multiple bands are present in the supernatant at $24 \mathrm{hpi}$, while in the supernatant from cells treated with tunicamycin a single band is present (lane 3). This band is immunoprecipitated by polyclonal serum that was produced against $E$. coli-expressed pGM-CSF (lane 6). These results are in agreement with published sequence data indicating that mature pGM-CSF has three potential N-linked glycosylation sites (Inumaru \& Takamatsu 1995). The inefficient immunoprecipitation of glycosylated pGM-CSF (lane 5) may be the result of interference with the antigen-antibody reaction by the extensive glycosylation of this protein. We further analyzed production of pGM-CSF in IB-RS-2 cells by Western blot analysis and show glycosylated pGM-CSF is efficiently detected, suggesting that denatured protein is a better antigen for this polyclonal antibody (compare Fig. 2, lanes 6 and 7 to Fig. 1, lane 5).

To examine the expression of $01 \mathrm{C}$ capsid proteins by Ad5O1C, IB-RS-2 infected cells were radiolabeled, cell lysates prepared at 5-7 hpi, immunoprecipitated with various FMDV-specific antibodies, and analyzed by SDS-PAGE (Fig. 3). We and others have previously shown that the $\mathrm{A} 12 \mathrm{C}$ protease can efficiently process the P1-2A precursor from A24, O1C, and 01 Taiwan/99 (Sa-Carvalho et al. 1997, Almeida et al. 1998, Moraes et al. 2002, Wu et al. 2003b unpublished). Reaction with bovine convalescent serum precipitated the structural proteins VP0, VP3, and VP1 (lanes 2 and 4). Likewise monospecific polyclonal antibodies against FMDV A12 VP1 and VP2, which we have previously demonstrated immunoprecipitates 01C structural proteins (Grubman et al. 1987), each precipitates all 3 O1C structural proteins (lanes 5 and 6) suggesting that FMDV capsid protein complexes are assembled in Ad5-O1C infected cells. We have previously observed similar results in cells infected with other 


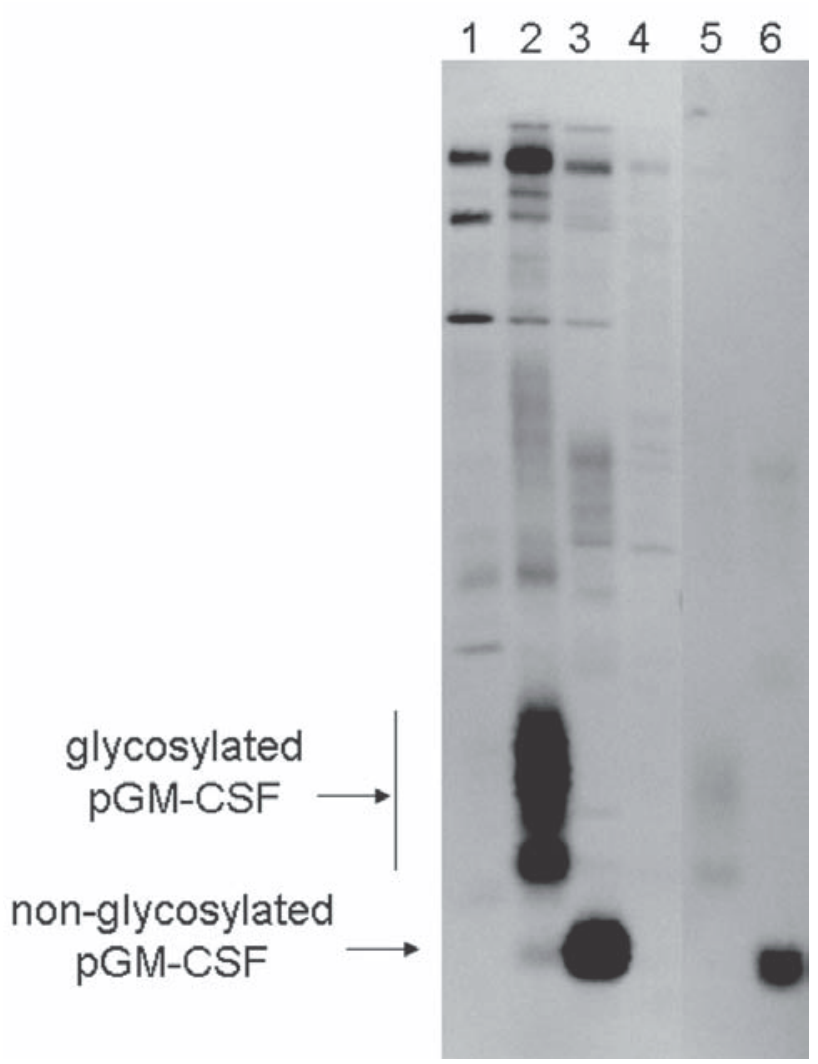

Fig.1. Expression of pGM-CSF in Ad5-pGMCSF infected IB-RS-2 cells. IB-RS-2 cells were infected with Ad5-pGMCSF and radiolabeled with $\left.{ }^{35} \mathrm{~S}\right]$ methionine in the absence or presence of tunicamycin. Supernatant fluids were harvested and proteins were resolved by SDS-PAGE on a $15 \%$ gel or immunoprecipitated with a polyclonal antibody against pGM-CSF and subsequently resolved by SDSPAGE. Lane 1: Supernatant fluid from cells infected for $6 \mathrm{~h}$ and radiolabeled in the absence of tunicamycin. Lanes 2-3: Supernatant fluids from cells infected for $24 \mathrm{~h}$ and radiolabeled in the absence or presence of tunicamycin, respectively. Lane 4: Immunoprecipitation of supernatant fluids from mock-infected, radiolabeled cells. Lanes 5-6: Immunoprecipitation of supernatant fluids from cells infected for $24 \mathrm{~h}$ and radiolabeled in the absence or presence of tunicamycin, respectively.

Ad5-FMDV viruses (Mayr et al. 1999, Moraes et al. 2002, Wu et al. 2003b)

The biological activity of pGM-CSF obtained from supernatant fluids of Ad5-pGMCSF infected IB-RS-2 was measured in vitro by a TF-1 cell proliferation assay. As shown in Fig. 4, Ad5 expressed pGM-CSF has biological activity as demonstrated by the support of TF-1 cell growth, while supernatant fouids from a control Ad5 lacking the pGM-CSF gene, Ad5-Blue, had no biological activity.

\section{Immune response prior to challenge}

To examine the potency and efficacy of Ad5-01C in susceptible animals and determine if pGM-CSF can enhance the immune response of the FMDV antigens, 3 groups of swine, 4 animals per group, were inoculated IM with Ad5-O1C at $5 \times 10^{9}$ $\mathrm{pfu} / \mathrm{ml}$ in the absence (Group 3) or presence of $1 \times 10^{8}$ or $1 \times 10^{9}$

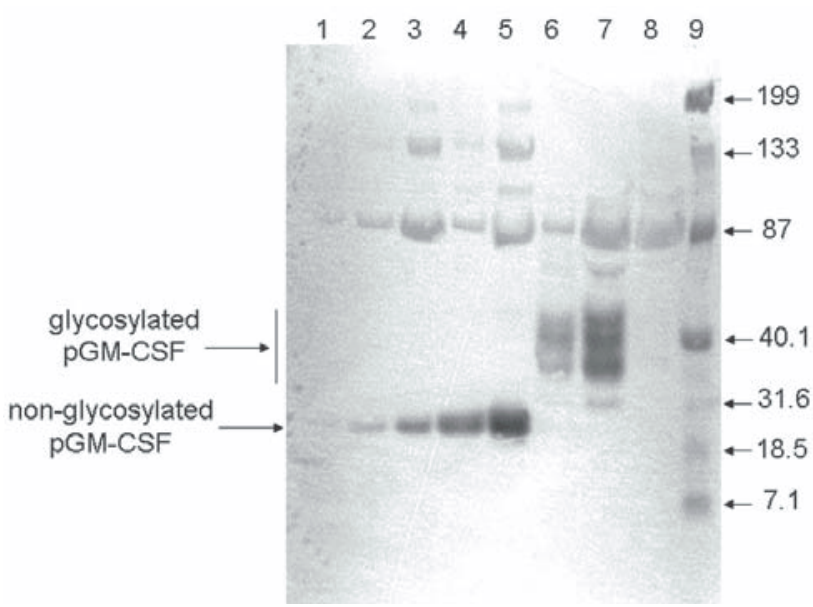

Fig.2. Western blot analysis of supernatant fluids from Ad5-pGMCSF infected IB-RS-2 cells. Samples were resolved on a precast $10 \%$ polyacrylamide gel, transferred to a membrane and detected with a polyclonal goat anti-pGM-CSF antibody. Lanes 1-5: 0.5, 1, 5, 10, and $20 \mathrm{ng}$ of recombinant pGM-CSF. Lanes 6-7: 2 and $9.8 \mu \mathrm{l}$ supernatant fluids from Ad5-pGMCSF infected IB-RS-2 cells. Lane 8: $9.8 \mu \mathrm{l}$ supernatant fluid from mock-infected IB-RS-2 cells. Lane 9: molecular weight marker. The numbers on the right represent molecular mass in kilodaltons.

pfu/animal Ad5-pGMCSF (Groups 4 and 5, Table 1). Control groups, 3 animals per group, were inoculated with an Ad5 vector, Ad5-Blue (Group 1), or with Ad5-pGMCSF alone (Group 2).

After vaccination no adverse side effects, such as fever, apathy or inflammation at the inoculation site, were observed in any of the pigs. The FMDV-specific neutralizing antibody titers of the Ad5-01C inoculated animals were detectable by 4-7 dpi, but were low and were not increased by co-administration of Ad5-pGMCSF (Table 1, Fig. 5). As expected the animals in the control groups did not develop an FMDV-specific neutralizing antibody titer.

\section{Clinical response after challenge}

All animals were challenged $21 \mathrm{dpv}$. After challenge, swine in the control groups ( 1 and 2 ) developed a fever (temperature of $40^{\circ} \mathrm{C}$ or higher for 2 or more consecutive days) by $1-2 \mathrm{dpc}$ and vesicular lesions by $1 \mathrm{dpc}$. All of these animals had extensive disease by 2-3 dpc (Fig. 6). Between 3-5 dpc all animals in control group 1, that received the Ad5-Blue vector, died and on day 3 one animal in group 2, that received Ad5-pGMCSF, also died. Upon necropsy, these four animals all had extensive signs of heart necrosis (tiger heart) which was confirmed by histopathological examination. These cardiac complications are typical causes of death as a result of FMDV infection in young swine. The two control animals that survived each lost at least one hoof by one week postchallenge.

Nine of twelve of the vaccinated pigs (Groups 3, 4 and 5) developed fever by $2-5 \mathrm{dpc}$, while 1 pig in group 3 and two in group 4 never had fever. All vaccinated swine developed signs of infection, but the onset of disease was delayed 1-2 days compared to the controls, disease severity was reduced, and no animals in these groups died or lost their hoofs (Fig. 6). The group that received only Ad5-01C (Group 3) had a slightly reduced clinical 


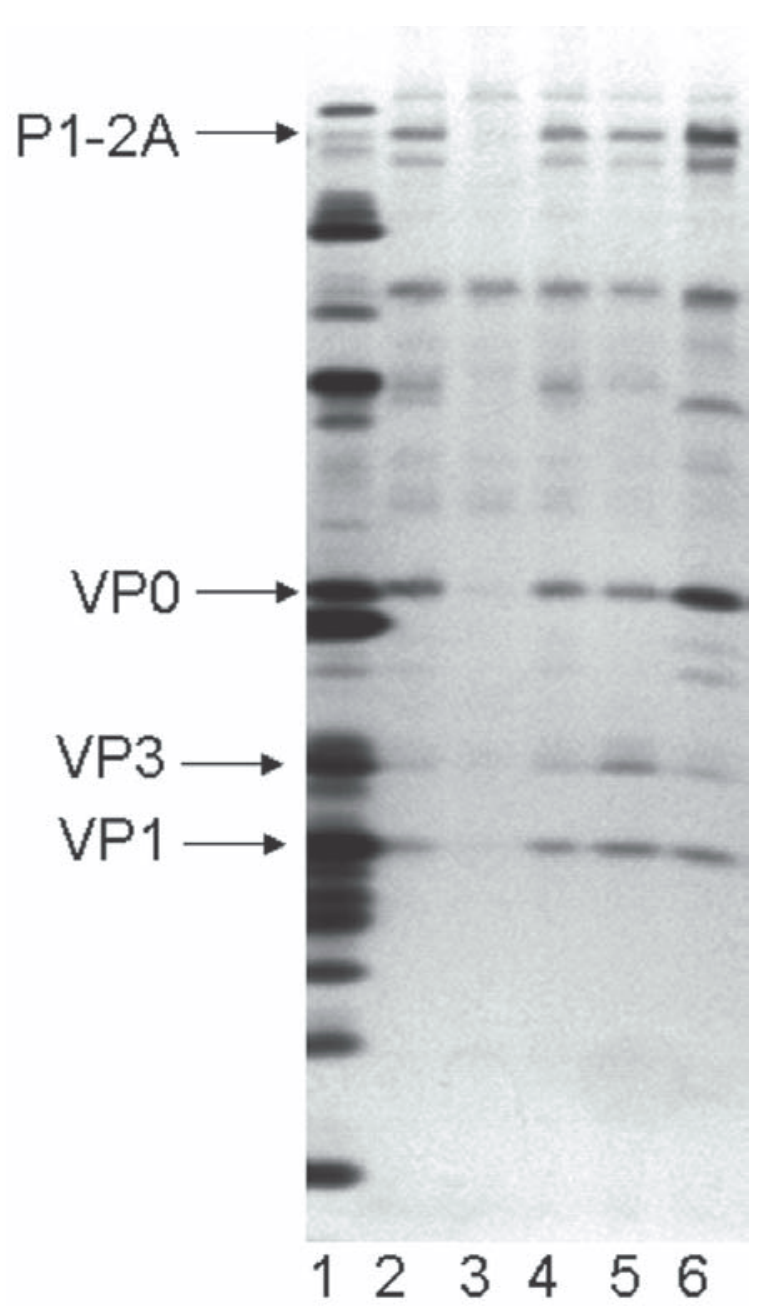

Fig.3. Expression of 01C capsid proteins in Ad5-O1C infected IB-RS-2 cells. ${ }^{35} \mathrm{~S} \mid$ methionine labeled lysates from Ad5-O1C infected IBRS-2 cells were immunoprecipitated with various antibodies and proteins resolved by SDS-PAGE on a $15 \%$ gel. Lane 1: An FMDV O1C infected IB-RS-2 cell lysate was immunoprecipitated with convalescent serum from a bovine infected with FMDV. Lanes 2-6: cell lysates from Ad5-O1C infected IB-RS-2 cells were immunoprecipitated with convalescent serum from a bovine infected with several serotypes (lane 2), normal bovine serum (lane 3), convalescent serum from a bovine infected with FMDV O1C (lane 4), or polyclonal antibodies against FMDV A12 VP1 and VP2 (lanes 5 and 6 , respectively).

score as compared to the groups that received both Ad5-O1C and Ad5-pGMCSF (Groups 4 and 5).

\section{Serological response after challenge}

The two surviving animals in the control groups became FMD positive by $7 \mathrm{dpc}$ and all animals in the FMD vaccinated groups developed a substantial increase in FMDV-specific neutralizing antibody response after challenge (Table 1, Fig. 5).

In both control groups viremia was detected at $1 \mathrm{dpc}$ and reached a peak of $1.5-3.5 \times 10^{6} \mathrm{pfu} / \mathrm{ml}$ at $2 \mathrm{dpc}$ (Fig. 7A). In the

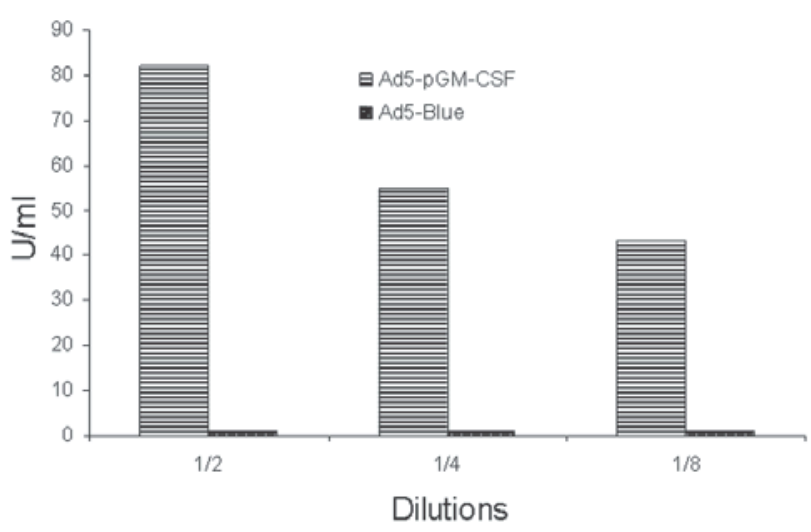

Fig.4. BrdU proliferation assay. Recombinant pGM-CSF was added to TF- 1 cells and examined for incorporation of BrdU to generate a standard curve. In the same assay supernatant fluids from Ad5pGMCSF and Ad5-Blue infected IB-RS-2 cells were titrated on TF1 cells and examined for cell proliferation. The units/ml of pGMCSF activity was determined from the standard curve $(1$ unit $=$ 100 pg pGM-CSF).

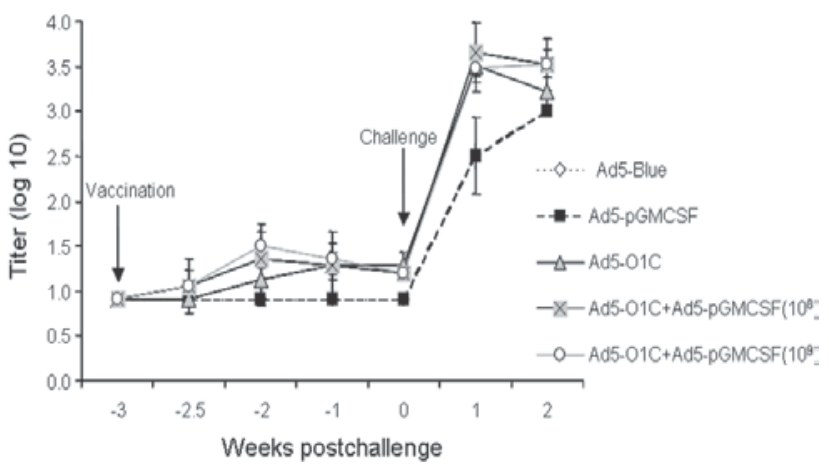

Fig.5. Kinetics of induction of FMDV-specific neutralizing antibody titers after Ad5 inoculation. Serum samples were obtained weekly after Ad5 inoculation until 2 weeks postchallenge. The FMDVspecific $\mathrm{PRN}_{70}$ titers were determined and expressed as the mean of each group.

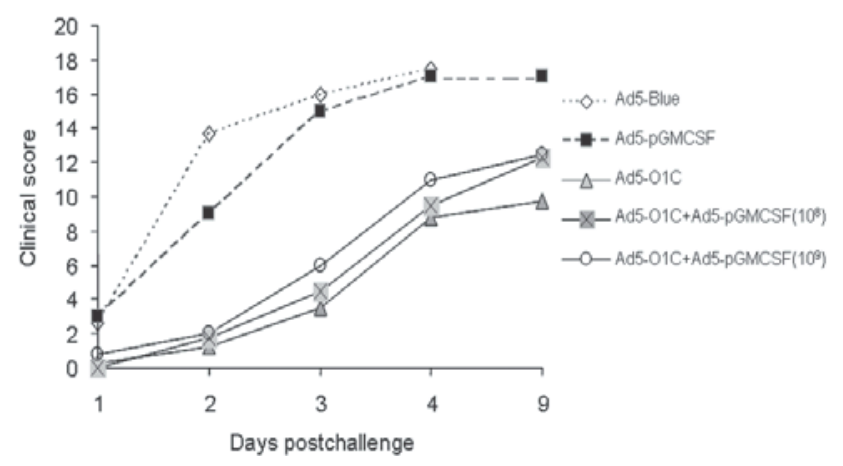

Fig.6. Appearance of clinical disease after FMDV challenge. Animals were examined daily for vesicular lesions and the clinical score was determined as described in the legend to Table 1 . The mean of each group is presented. 

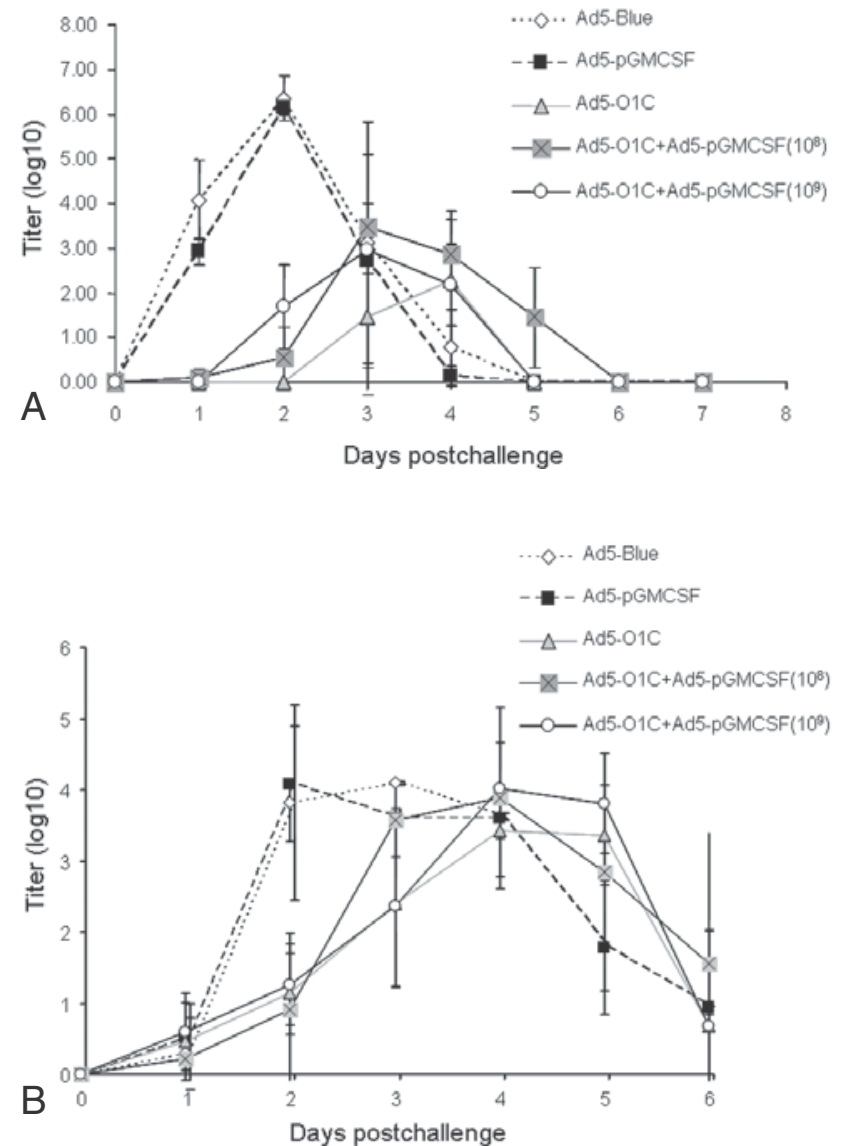

Fig.7. Virus present in blood and nasal secretions after challenge. Panel A: Viremia in Ad5 inoculated pigs after FMDV challenge. Blood samples were obtained daily for 7 days postchallenge and virus titers, $\mathrm{pfu} / \mathrm{ml}$, determined by plaque assay on BHK-21 cells. The mean of each group is displayed. Panel B: Virus in nasal swabs of Ad5 inoculated pigs after FMDV challenge. Nasal swabs were obtained daily for 6 days postchallenge and virus titers, pfu/ $\mathrm{ml}$, determined by plaque assay on BHK-21 cells. The mean of each group is displayed.

FMD vaccinated groups, viremia was first detected in groups 4 and 5 (vaccine + pGMCSF) at 2-3 dpc and by 3-4 dpc in group 3 (vaccine alone). One pig in group 3 never developed viremia or fever and a second animal only had a low level of viremia for 1 day (Fig. 7A). Peak viremia was at $3 \mathrm{dpc}$ in the dual-inoculated groups and was approximately 1,000 -fold lower as compared to the controls (Fig. 7A). In the Ad5-01C vaccinated animals, peak viremia was at $4 \mathrm{dpc}$ and was approximately 10,000-fold lower than in the control pigs.

Virus present in nasal swabs reached a peak in both control groups by $2-3 \mathrm{dpc}$ and at $4 \mathrm{dpc}$ in all three FMD vaccinated groups (Fig. 7B). Group 3, vaccinated with only Ad5-O1C, had the lowest levels of virus shedding.

\section{DISCUSSION}

We have previously demonstrated that a single IM inoculation of Ad5-FMDV vectors containing the P1-2A coding regions from
A12 (Mayr et al. 2001) or A24 (Moraes et al. 2002) and the A12 3C protease coding region can induce significant FMDV-specific neutralizing antibody titers in swine and protect most or all of the animals when challenged either by contact or direct inoculation. However, inoculation with an Ad5 vector containing the $01 \mathrm{C}$ capsid coding region or an $\mathrm{Ad} 5$ vector containing the O1C capsid coding region in a bicistronic expression cassette induces a significantly lower FMDV-specific neutralizing antibody response in swine (unpublished observations; Wu et al. 2003b). Similar results have been reported with the conventional inactivated FMD vaccine and therefore to be an efficacious vaccine, manufacturers include a higher dose of type $0146 \mathrm{~S}$ antigen than type A in vaccine formulations (Pay \& Hingley 1987, Doel et al. 1994).

To enhance the immune response induced by Ad5-01C, we tested a vaccination regimen that included co-administration of pGM-CSF, a cytokine that has been shown to enhance the immune response of animals to some vaccines (Xiang \& Ertl 1995, Lee et al. 1998, Somasudaran et al. 1999, Cedillo-Barrón et al. 2001, Barouch et al. 2002). We constructed an Ad5-pGMCSF virus that expressed biologically active pGM-CSF. Swine inoculated with Ad5-01C and either a low or high dose of Ad5-pGMCSF developed a detectable FMDV-specific neutralizing antibody response prior to the animals administered only Ad5-01C, ie., by 4 days, and the response was higher at 1 week postinoculation. However, by 2 weeks postinoculation and at the time of challenge the neutralizing antibody response of these 3 groups was equivalent (Fig. 5) and was considerably lower than the response to one inoculation of Ad5-A12 or Ad5-A24 (Mayr et al. 2001, Moraes et al. 2002). Thus, the co-administration of Ad5-pGMCSF did not enhance the long-term FMDV-specific neutralizing antibody response.

After challenge the control groups (Groups 1 and 2) rapidly developed significant disease and all 3 animals in Group 1 and one of 3 animals in Group 2 died. The histopathology findings upon necropsy of the four animals that died after challenge revealed that they all had severe vesicular lesions on the mouth and all feet, resembling typical FMD lesions, and moderate to severe myocardial necrosis resulting in heart failure, which was most likely the result of FMDV infection. In previous experiments with FMDV serotype A, control groups of swine rapidly developed significant disease after direct inoculation challenge, but did not die if they were healthy prior to the start of the experiment (Moraes et al. 2002, Chinsangaram et al. 2003, Moraes et al. 2003), suggesting that the challenge virus used in the present studies was either too virulent or the dose used was excessive. In subsequent titration of this virus, $1 / 100^{\text {th }}$ the dose used in this study still resulted in the death of 1 of 2 naïve animals and the animal that survived had severe disease including loss of hoofs. In either case the "over-challenge", in this experiment, masked the protective effects of the Ad5-01C vaccine, since all vaccinated animals developed vesicular lesions and 3 of 4 animals had viremia. However, vaccination with Ad5-01C clearly delayed and reduced the severity of disease. None of the animals inoculated with only Ad5-01C died or lost their hoofs, the appearance of vesicular lesions was delayed for 1- 
2 days as compared to the control groups and was less severe. Furthermore, the peak of viremia was delayed 2 days, one animal never developed viremia, and virus titers were approximately 10,000 -fold lower than in the controls, and the peak of virus shedding was delayed 2 days.

The addition of pGM-CSF did not enhance the efficacy of the Ad5-01C vaccine. Although none of the animals given Ad5pGMCSF died or lost their hoofs, all developed vesicular lesions that were somewhat more severe than the Ad5-01C vaccinated animals. Furthermore, while viremia was delayed and reduced as compared to the control groups all of these effects can be attributed to the vaccine alone, as the Ad5-O1C inoculated animals had even lower levels of viremia.

We have subsequently repeated this experiment, and included a second route of inoculation, and obtained very similar results. Swine inoculated with Ad5-01C IM with a needle or subcutaneously/IM by needleless delivery and challenged had no detectable viremia and clinical disease was delayed and less severe than control animals (data not shown). However, the addition of Ad5-pGMCSF reduced the level of protection afforded by the vaccine alone.

Cedillo-Barrón et al. (2001) demonstrated that the addition of plasmid encoded pGM-CSF along with a DNA based FMDV empty capsid vaccine resulted in a statistically significant increase in the antibody levels against FMDV and somewhat improved the protection of vaccinated swine as compared to swine only given the empty capsid vaccine. However, in these studies the swine were challenged after 3 DNA inoculations and the increase in FMDV-specific antibody levels was only detected after the second inoculation. Additional studies examining the adjuvant effect of GM-CSF for other antigens have suggested that the presence of this cytokine at the site of vaccine inoculation is important (Wang et al. 2002) and that plasmids co-expressing antigen and GM-CSF are more effective than co-administration of plasmids separately expressing each antigen (Lee et al. 1998, Barouch et al. 2002, Sun et al. 2002).

While our results do not agree with the findings of CedilloBarrón et al. (2001), it may be that factors including the level of expression of both the immunogen and the adjuvant, the type of cells expressing these proteins, as well as the proximity of antigen and adjuvant expression in the animal can have profound effects on induction of protective responses. Experiments to examine these factors as well as a more basic understanding of the host cell response to FMDV infection may help us identify cytokines that can potentially enhance the immune response to FMD vaccine candidates.

\section{CONCLUSION}

In previous work, we have demonstrated that swine given one dose of an Ad5-O1C vector developed only low FMDV-specific neutralizing antibody titers. To attempt to enhance the potency and efficacy of this vaccine, groups of swine were given either one inoculation of an Ad5-01C vector or a combination of Ad5$\mathrm{O} 1 \mathrm{C}$ and an Ad5 vector containing the cytokine pGM-CSF at two different doses. Animals were challenged 3 weeks later by direct inoculation with virulent FMDV. Although the swine inoculated with only Ad5-01C did not develop a significant FMDV-specific neutralizing antibody response and did develop clinical disease after challenge, disease signs and viremia were considerably reduced as compared to control groups. While the addition of Ad5-pGMCSF induced a more rapid neutralizing antibody response, it adversely affected the level of protection afforded by the Ad5-01C vaccine alone.

Acknowledgements.- We are thankful to Marla Koster, Dr. Elida Bautista and Dr. Vladmir G. Andreyev for their technical assistance, Dr. Peter W. Mason for providing the FMDV 01 Campos challenge virus and plasmid pCRM8, the Plum Island animal caretakers for their assistance with the swine, and the USDA-ARS for financial support.

\section{REFERENCES}

Almeida M.R., Rieder E., Chisangaram J., Ward G., Beard C., Grubman M.J. \& Mason P.W. 1998. Construction and evaluation of an attenuated vaccine for foot-and-mouth disease: difficulty adapting the leader proteinasedeleted strategy to the serotype 01 virus. Virus Res. 55:49-60.

Barouch D.H., Santra S., Tenner-Racz K., Racz P., Kuroda M.J., Schmitz J.E., Jackson S.S., Lifton M.A., Freed D.C., Perry H.C., Davies M-E., Shiver J.W. \& Letvin N.L. 2002. Potent CD4+ T cell responses elicited by a bicistronic HIV1 DNA vaccine expressing gp120 and GM-CSF. J. Immun. 168:562-568.

Barteling S.J. \& Vreeswijk J. 1991. Developments in foot-and-mouth disease vaccines. Vaccine 9:75-88.

Bautista E.M., Gregg D. \& Golde W.T. 2002. Characterization and functional analysis of skin-derived dendritic cells from swine without a requirement for in vitro propagation. Vet. Immun. Immunopath. 88:131-148.

Benvenisti L., Rogel A., Kuznetzova L., Bujanover S., Becker Y. \& Stram Y. 2001. Gene gun-mediated DNA vaccination against foot-and-mouth disease virus. Vaccine 19:3885-3895.

Berinstein A., Tami C., Taboga O., Smitsaart E. \& Carrillo E. 2000. Protective immunity against foot-and-mouth disease virus induced by a recombinant vaccinia virus. Vaccine 18:2231-2238.

Bittle J.L., Houghten R.A., Alexander H., Shinnick T.M., Sutcliffe J.G., Lerner R.A., Rowlands D.J. \& Brown F. 1982. Protection against foot-and-mouth disease by immunization with a chemically synthesized peptide predicted from the viral nucleotide sequence. Nature 298:30-33.

Blanco E., Garcia-Briones M., Sanz-Parra A., Gomes P., De Oliveira E., Valero M.L., Andreu D., Ley V. \& Sobrino F. 2001. Identification of T-cell epitopes in nonstructural proteins of foot-and-mouth disease virus. J. Virol. 75:3164-3174.

Brown F. 1988. Use of peptides for immunization against foot-and-mouth disease. Vaccine 6:180-182.

Brownlie J. 2001. Strategic decisions to evaluate before implementing a vaccine programme in the face of a foot-and-mouth disease (FMD) outbreak. Vet. Rec. 148: 358-360.

Burrows R. 1966. The foot-and-mouth disease virus in pigs. J. Hyg. Camb. 64:419-429.

Callis J.J. \& McKercher P.D. 1986. Foot-and-mouth disease, p.337. In: Leman (ed.) Diseases of Swine. Iowa State University Press, Ames.

Cedillo-Barrón L., Foster-Cuevas M., Belsham G.J., Lefèvre F. \& Parkhouse, R.M.E. 2001. Induction of a protective response in swine vaccinated with DNA encoding foot-and-mouth disease virus empty capsid proteins and the 3D RNA polymerase. J. Gen. Virol. 82:1713-1724.

Chinsangaram J., Beard C., Mason P.W., Zellner M.K., Ward G. \& Grubman M.J. 1998. Antibody response in mice inoculated with DNA expressing foot-and-mouth disease virus capsid proteins. J. Virol. 72:4454-4457.

Chinsangaram J., Moraes M.P., Koster M. \& Grubman M.J. 2003. Novel viral disease control strategy: adenovirus expressing alpha interferon rapidly protects swine from foot-and-mouth disease. J. Virol. 77:16211625.

Clarke B.E., Carroll A.R., Rowlands D.J., Nicholson B.H., Houghten R.A., 
Lerner R.A. \& Brown F. 1983. Synthetic peptides mimic subtype specificity of foot-and-mouth disease virus. FEBS Lett. 157:261-264.

Doel T.R., Williams L. \& Barnett P.V. 1994. Emergency vaccination against foot-and-mouth disease: rate of development of immunity and its implications for the carrier state. Vaccine 12:592-600.

Donaldson A.I. 1986. Aerobiology of foot-and-mouth disease (FMD): an outline and recent advances. Rev. Sci. Tech. Off. Int. Epizoot. 5:315-321.

Graham F.L. \& Prevec L. 1991. Manipulation of adenovirus vectors, 109128. In: Murray, E.J. (ed.) Methods in Molecular Biology. The Humana Press, Clinton, NJ.

Graham F.L., Smiley J., Russell W.C. \& Nairn R. 1977. Characteristics of a human cell line transformed by DNA from human adenovirus 5 . J. Gen Virol. 36:59-74

Grubman, M.J., Zellner, M., Wagner, J. 1987. Antigenic comparison of the polypeptides of foot-and-mouth disease virus serotypes and other picornaviruses Virology 158:133-140.

He T.C., Zhou S., Costa L.T., Yu J., Kinzler K.W. \& Vogelstein B. 1998. A simplified system for generating recombinant adenoviruses. Proc. Natl Acad. Sci., USA. 95: 2509-2514.

Inumaru S. \& Takamatsu H. 1995. cDNA cloning of porcine granulocytemacrophage colony-stimulating factor. Immunol. Cell Biol. 73:474-476.

Kitamura T., Tange T., Terasawa T., Chiba S., Kuvaki T., Miagawa K., Piao Y., Miyozano K., Urabe A. \& Takaku F. 1989. Establishment and characterization of a unique human cell line that proliferates dependently on GM-CSF, IL-3, or erythropoietin. J. Cell Physiol. 140:323-334.

Kleid D.G., Yansura D., Small B., Dowbenko D., Moore D.M., Grubman M.J., McKercher P.D., Morgan D.O., Robertson B.H. \& Bachrach H.L. 1981. Cloned viral protein vaccine for foot-and-mouth disease: responses in cattle and swine. Science 214:1125-1129.

Kusakabe K., Xin K-Q., Katoh H., Sumino K., Hagiwara E., Kawamoto S., Okuda K., Miyagi Y., Aoki I., Nishioka K., Klinman D. \& Okuda K. 2000. The timing of GM-CSF expression plasmid administration influences the Th1/Th2 response induced by an HIV-1-specific DNA vaccine. J. Immun. 164:3102-3111.

Lee S.W., Cho J.H. \& Sung Y.C. 1998. Optimal introduction of hepatitis C virus envelope-specific immunity by bicistronic plasmid DNA inoculation with the granulocyte-macrophage colony-stimulating factor gene. J. Virol. 72:8430-8436.

Mason P.W., Piccone M.E., McKenna T.S., Chinsangaram J. \& Grubman M.J 1997. Evaluation of a live-attenuated foot-and-mouth disease virus as a vaccine candidate. Virology 227:96-102

Matthews J. 2001. Foot-and-mouth disease outbreak. Vet. Rec. 148: 282.

Mayr G.A., Chinsangaram J. \& Grubman M.J. 1999. Development of replication-defective adenovirus serotype 5 containing the capsid and 3C protease coding regions of foot-and-mouth disease virus as a vaccine candidate. Virology 263:496-506.

Mayr G.A., O’Donnell V., Chinsangaram J., Mason P.W. \& Grubman M.J. 2001. Immune responses and protection against foot-and-mouth disease virus (FMDV) challenge in swine vaccinated with adenovirus-FMDV constructs. Vaccine 19:2152-2162.

McKercher P.D., Moore D.M., Morgan D.O., Robertson B.H., Callis J.J., Kleid D.G., Shire S.J., Yansura D.G., Dowbenko D. \& Small B. 1985. Doseresponse evaluation of a genetically engineered foot-and-mouth disease virus polypeptide immunogen in cattle. Am. J. Vet. Res. 46:587-590.

Moraes M.P., Chinsangaram J., Brum M.C.S. \& Grubman M.J. 2003. Immediate protection of swine from foot-and-mouth disease: a combination of adenoviruses expressing interferon alpha and a footand-mouth disease virus subunit vaccine. Vaccine 22:268-279.

Moraes M.P., Mayr G.A., Mason P.W. \& Grubman M.J. 2002. Early protection against homologous challenge after a single dose of replication-defective human adenovirus type 5 expressing capsid proteins of foot-and-mouth disease virus (FMDV) strain A24. Vaccine 20:1631-1639.

Moraes M.P., Mayr G.A. \& Grubman M.J. 2001. pAd5-Blue: direct ligation system for engineering recombinant adenovirus constructs. Biotechniques 31:1054-1056.

Murphy F.A., Gibbs E.P., Horzinek M.C. \& Studdert M.C. 1999. Veterinary Virology. 3rd ed. Academic Press, New York.

Pay T.W. \& Hingley P.J. 1987. Correlation of 140 S antigen dose with the serum neutralizing antibody response and the level of protection induced in cattle by foot-and-mouth disease vaccines. Vaccine 5:60-64.

Sa-Carvalho D., Rieder E., Baxt B., Rodarte R., Tanuri A. \& Mason, P.W. 1997. Tissue culture adaptation of foot-and-mouth disease virus selects viruses that bind to heparin and are attenuated in cattle. J. Virol. $71: 5115-5123$

Sanz-Parra A., Jimenez-Clavero M.A., Garcia-Briones M.M., Blanco E., Sobrino F. \& Ley V. 1999a. Recombinant viruses expressing the foot-and-mouth disease virus capsid precursor polypeptide (P1) induce cellular but not humoral antiviral immunity and partial protection in pigs. Virology 259:129-134

Sanz-Parra A., Vazquez B., Sobrino F., Cox S.J., Ley V. \& Salt J.S. 1999b. Evidence of partial protection against foot-and-mouth disease in cattle immunized with a recombinant adenovirus vector expressing the precursor polypeptide (P1) of foot-and-mouth disease virus capsid proteins. J. Gen. Virol. 80:671-679.

Sin J.-I., Sung J.-H., Suh Y.-S., Lee A.-H., Chung J.-H. \& Sung Y.-C. 1997. Protective immunity against heterologous challenge with encephalomyocarditis virus by VP1 DNA vaccination: effect of coinjection with a granulocyte-macrophage colony stimulating factor gene. Vaccine 15:1827-1833.

Somasundaram C., Takamatsu H., Andréoni C., Audonnet J.-C., Fischer L., Lefèvre F. \& Charley B. 1999. Enhanced protective and immuno-adjuvant effects of porcine GM-CSF on DNA vaccination of pigs against Aujeszky's disease virus. Vet. Immunol. Immunopath. 70:277-287.

Sun X., Hodge L.M., Jones H.P., Tabor L. \& Simecka J.W. 2002. Co-expression of granulocyte-macrophage colony-stimulating factor with antigen enhances humoral and tumor immunity after DNA vaccination. Vaccine 20:1466-1474.

Wang J., Zganiacz A. \& Xing Z. 2002. Enhanced immunogenicity of BCG vaccine by using a viral-based GM-CSF transgene adjuvant formulation. Vaccine 20:2887-2898.

Ward, G., Rieder, E., Mason, P.W. 1997. Plasmid DNA encoding replicating foot-and-mouth disease virus genomes induces antiviral immune responses in swine. J. Virol. 71: 7442-7447.

Wong H.T., Cheng S.C.S., Chan E.W.C., Sheng Z.T., Yan W.Y., Zheng Z.X. \& Xie Y. 2000. Plasmids encoding foot-and-mouth disease virus VP1 epitopes elicited immune responses in mice and swine and protected swine against viral infection. Virology 278: 27-35.

Wu Q., Brum M.C.S., Caron L., Koster M. \& Grubman M.J. 2003a. Adenovirus-mediated type I interferon expression delays and reduces disease signs in cattle challenged with foot-and-mouth disease virus. J. Int. Cyt. Res. 23:2371-2380.

Wu Q., Moraes M.P. \& Grubman M.J. 2003b. Recombinant adenovirus co-expressing capsid proteins of two serotypes of foot-and-mouth disease virus (FMDV): in vitro characterization and induction of neutralizing antibodies against FMDV in swine. Virus Res. 93:211219

Xiang Z. \& Ertl H.C.J. 1995. Manipulation of the immune response to a plasmid-encoded viral antigen by coinoculation with plasmids expressing cytokines. Immunity 2:129-135. 